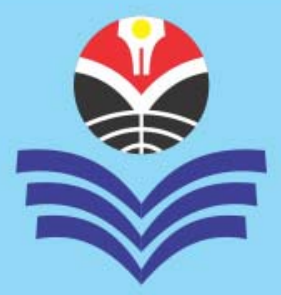

\title{
Ideologisasi Konsep Reformasi dalam Historiografi Buku Teks Pelajaran Sejarah di Sekolah
}

\begin{abstract}
ABSTRAKSI: Salah satu karya historiografi yang disusun dan dipublikasikan untuk tujuan pendidikan adalah buku teks pelajaran untuk SMA/MA (Sekolah Menengah Atas/Madrasah Aliyah), Kelas XII. Selain harus memenuhi syarat ilmiah, buku teks pelajaran sejarahpun disesuaikan dengan kebijakan dan kepentingan politik pendidikan dari pemerintah, yang termaktub dalam dan diwakili oleh kurikulum pendidikan sejarah. Dalam konteks ini, sejarah tidak diposisikan sebagai "sejarah untuk sejarah" atau sejarah dalam ruang kedap kepentingan, melainkan dijadikan alat pendidikan oleh pemerintah. Hal ini terlihat dari adanya ideologisasi (penyebarluasan ide dan pandangan) pemerintah terhadap peserta didik melalui buku teks pelajaran sejarah. Bentuk ideologisasi yang terdapat dalam historiografi buku teks pelajaran sejarah SMA/MA kelas XII diantaranya berupa ideologisasi konsep "reformasi". Dalam buku teks ini, bukan saja konsep "reformasi" itu bermakna dan diopinikan baik, manakala pada zaman Orde Baru bersifat buruk, melainkan juga para pembacanya diarahkan untuk menyetujui sikap tim penulis yang adalah juga sikap resmi pemerintah, bahwa pemerintahan Orde Baru yang buruk itu harus dikoreksi oleh pemerintahan Reformasi. Betapa pun masih mengalami banyak kendala, namun dikatakan bahwa "reformasi" ialah langkah tepat dan memberi optimisme bagi bangsa Indonesia dalam mencapai tujuan pembentukan negara-bangsa.

KATA KUNCI: Ideologisasi, buku teks, konsep reformasi, kepentingan pemerintah, dan politik pendidikan.
\end{abstract}

ABSTRACT: "The Ideologization Process of the Concept of Reform in the Historiography of History Textbooks in Schools". One of the works of historiography which is prepared and published for the purpose of education is textbooks for SMA/MA (Senior High School/Islamic Senior High School), grade twelve. In addition to fulfilling scientific requirements, history textbooks are suited to the educational policies and the political interests of the government, embodied in and represented by the curriculum of history education. In this context, history is not positioned as a "history for history" or history in the tight space of interests; rather, it is an educational tool of the government. This is evident from the process of ideologization (the dissemination of ideas and views) of the government towards learners through history textbooks. The form of ideologization process contained in the historiography of the history textbooks of SMA /MA grade twelve, among others, is the ideologization of "reform" concept. In the textbooks, not only is the concept of "reform" meaningful and well-regarded, which the New Order government era was considered bad, but readers are also directed to approve the attitude of a team of writers who are also the official stance of the government, that the New Order government was bad, and it should be corrected by the Reform government. Although there are still many obstacles, it can be said that "reform" is the right step and it gives optimism to the nation of Indonesia in achieving the goal of establishing the nation-state.

KEY WORD: Process of ideologization, textbooks, concept of reform, governments'interests, and politics of education.

About the Authors: Mi'raj Dodi Kurniawan, S.Pd. adalah Alumni Mahasiswa Pendidikan Sejarah UPI (Universitas Pendidikan Indonesia) dan Mahasiswa Program Magister S-2 Pendidikan Sejarah di Sekolah Pascasarjana UPI. Andi Suwirta, M.Hum. adalah Dosen Senior di Departemen Pendidikan Sejarah UPI Bandung. Alamat emel penulis: mirajdeka@yahoo.co.id dan suwirta.sahaja@upi.edu

How to cite this article? Kurniawan, Mi'raj Dodi \& Andi Suwirta. (2016). "Ideologisasi Konsep Reformasi dalam Historiografi Buku Teks Pelajaran Sejarah di Sekolah” in MIMBAR PENDIDIKAN: Jurnal Indonesia untuk Kajian Pendidikan, Vol.1(1) Maret, pp.55-68. Bandung, Indonesia: UPI Press.

Chronicle of the article: Accepted (January 25, 2016); Revised (February 25, 2016); and Published (March 11, 2016). 


\section{PENDAHULUAN}

Analisis historiografi buku teks pelajaran sejarah ini dilakukan berkenaan dengan ideologisasi konsep "Reformasi" dalam buku teks pelajaran sejarah di sekolah. Adapun buku yang akan dianalisis adalah sebagai berikut: (1) judul buku: Sejarah untuk SMA MA Kelas XII Program IPA; (2) jenis buku: BSE atau Buku Sekolah Elektronik; (3) landasan kurikulum: KTSP atau Kurikulum Tingkat Satuan Pendidikan; (4) tim penulis: Sh. Musthofa, Suryandari \& Tutik Mulyati; (5) editor: Himawan Prasetyo; (6) ilustrator: Haryana Humardani; (7) tahun terbit: 2009; (8) tempat terbit: Jakarta; (9) penerbit: Pusat Perbukuan Departemen Pendidikan Nasional; dan (10) jumlah halaman: viii + 178 Halaman.

Setidaknya ada empat syarat berdirinya negara dan - dengan demikian - harus dimiliki suatu negara: rakyat, wilayah, pemerintah, dan konstitusi. Empat hal tadi syarat de facto pembentukan negara, disamping syarat de jure yaitu pengakuan negara lain atas keberadaan negara tersebut. Selain syarat de facto dan syarat de jure tersebut, negara juga memerlukan legitimasi historis (penguatan dari aspek kesejarahan) untuk menyatukan dan mempertahankan negara (Budiardjo, 1985).

Legitimasi historis yang dimaksud adalah konstruksi fakta dan interpretasi terhadap masa lalu (sejarah), yang bukan saja menggiring warga negara terhadap pemahaman bahwa pembentukan negara ini masuk akal atau memiliki landasan (latar belakang) sejarahnya, namun juga menggambarkan alasan sekaligus visi pendirian negara. Konstruksi fakta dan interpretasi tadi bukan saja harus memenuhi syarat keilmiahan (sesuai kaidah keilmuan), namun juga didesain untuk kepentingan memperkuat keberadaan, kelanjutan, dan pencapaian tujuan negara (Wiriaatmadja, 2000).

Negara bukan hanya mencari, membuat, dan menyebarluaskan legitimasi historis, tetapi juga eksponen-eksponen pembentuk negara mencari, membuat, dan menyebarluaskan ideologi negara. Maka, legitimasi historis dan ideologi negara bukan hanya saling memperkuat, tetapi juga ditransmisikan dan ditranformasikan, sehingga menjadi keyakinan rakyat. Proses penyebarluasan legitimasi historis dan ideologi ini disebut “ideologisasi”, yaitu penyebarluasan keyakinan dan pandangan sehingga menjadi keyakinan dan pandangan warga bangsa.

Ideologi, mungkin sekali, tumbuh dari kepentingan dan pemikiran manusia, namun bisa pula karena pengaruh agama. Pengaruh lingkungan dan tradisi serta pemikiran dari luar turut pula mewarnai ideologi (Noer, 1982:29). Dengan demikian, terdapat beberapa faktor yang mempengaruhi terbentuknya ideologi, diantaranya faktor kepentingan dan pemikiran manusia, faktor agama, faktor lingkungan, faktor tradisi, dan faktor pengaruh pihak luar. Menurut Louis Althusser (t.t.), ideologi merepresentasikan hubungan imajiner dari individu-individu pada kondisi eksistensinya yang nyata (Althusser, t.t.:xi).

Dengan didukung, bahkan diinisiasi dan dipengaruhi negara (pemerintah), maka suatu legitimasi historis biasanya diteliti terlebih dahulu oleh para ahli sejarah dan disebarkan oleh negara kepada warganya melalui - meminjam istilah Louis Althusser (t.t.) - ideological state apparatus atau aparat negara ideologis. Ideologisasi ditempuh oleh aparat negara ideologis melalui ideologi (secara halus) - untuk membedakannya dengan repressive state apparatus (aparat negara represif), yang bekerja melalui kekerasan (Althusser, t.t.:21).

Aparat negara represif - sebagaimana dapat ditemukan dalam teori Marxis diantaranya berupa pemerintah, administrasi, angkatan bersenjata, polisi, pengadilan, penjara, dan sebagainya (Althusser, t.t.:19); sedangkan aparat negara ideologis diantaranya berbentuk institusi agama, pendidikan, keluarga, hukum, politik, serikat 
buruh, komunikasi, dan budaya (Althusser, t.t.:20).

Aparat negara ideologis tidak hanya berfungsi secara masif dan berkuasa lewat ideologi, tetapi juga berfungsi secara sekunder melalui represi pula, bahkan dalam tingkatan tertinggi - tetapi hanya pada akhirnya - fungsi ini menjelma sangat halus dan tersembunyi, bahkan simbolik (Althusser, t.t.:22). Artinya, ideologisasi oleh aparat negara ideologis tampak semakin tidak kentara dalam menciptakan - meminjam istilah yang dipopulerkan Antonio Gramsci - "hegemoni” (dalam Hoare \& Smith eds., 1971).

Jika mengikuti alur berpikir dari Louis Althusser (t.t.) tadi, maka institusi pendidikan merupakan atau termasuk sebagai salah satu bentuk aparat negara ideologis. Institusi pendidikan - sebagai kepanjangan dari negara - yang bekerja melalui ideologi, ditandai dengan adanya kurikulum, materi, dan evaluasi pendidikan yang dibuat oleh negara atau pemerintah. Karena itu mudah dipahami bahwa ilmu sejarah yang digunakan untuk kepentingan - ideologisasi - negara, diantaranya tampak dalam materi pelajaran sejarah yang diajarkan terhadap peserta didik di sekolah.

Satu dari sekian praktek ideologisasi negara melalui aparat pendidikan, berkenaan dengan aspek ideologi dan legitimasi historis itu, tampak dalam bentuk buku teks pelajaran sejarah. Sebagai sebuah karya tulis sejarah, buku teks pelajaran sejarah pun adalah karya historiografi. Namun, berbeda dengan jenis historiografi lainnya - terutama historiografi yang berorientasi kesejarahan semata-mata dan tanpa maksud politik pendidikan historiografi buku teks pelajaran sejarah merupakan genre historiografi, yang berusaha memenuhi standar ilmu sejarah sekaligus untuk kepentingan pendidikan (Hasan, 2000; dan Wiriaatmadja, 2003; dan Suwirta, 2010). Ia medium ideologisasi negara terhadap peserta didik.

Buku teks pelajaran sejarah tidaklah muncul di Indonesia pasca merdeka, melainkan ketika masih sebagai Hindia Belanda di bawah penjajahan Belanda pun telah hadir dan diajarkan, tentu saja terhadap kalangan pelajar yang terbatas dan bersifat kolonial atau Belanda-sentris. Michael Wood (2013) menerangkan secara ringkas, namun jelas, tentang perkembangan penggunaan buku pelajaran sejarah dan tipe narasi sejarah yang dikembangkan sejak zaman kolonial Belanda hingga zaman Orde Baru. Menurut hasil studinya, ideologisasi melalui buku teks pelajaran sejarah bukanlah hal baru (Wood, 2013:42-50).

Menurut Helius Sjamsuddin (2007), historiografi buku teks pelajaran sejarah merupakan rekonstruksi materi sejarah berbentuk uraian narasi, yang dijadikan rujukan materi dalam mengajarkan sejarah. Ketimbang sebagai sejarah penulisan sejarah, pengertian historiografi dalam penulisan buku teks pelajaran sejarah ini lebih cenderung sebagai metode. Maksudnya, historiografi jenis ini merupakan langkah penelitian sejarah dengan menafsirkan, menjelaskan, dan menyajikan suatu tulisan sejarah (Sjamsuddin, 2007:155-271).

Menurut Agus Mulyana (2013), penulisan buku teks pelajaran sejarah ditujukan untuk kepentingan pendidikan. Lantaran dijadikan alat pendidikan, maka ia (buku teks pelajaran sejarah) akan dipengaruhi oleh landasan ideologi pendidikan yang dianut oleh negara tersebut. Ketika landasan ideologi dijadikan dasar penulisannya, maka akan munculah interpretasi dari pihak pembuat kebijakan pendidikan, yaitu pemerintah. Dengan kata lain, historiografi buku teks pelajaran sejarah bukan saja merupakan suatu bentuk ideologisasi negara atau pemerintah, melainkan juga bersifat politik (Mulyana, 2013:78).

Jadi, tujuan dari penyusunan buku teks pelajaran sejarah adalah untuk kepentingan pendidikan sejarah. Ia rekonstruksi narasi sejarah yang dijadikan alat pendidikan, dan karena itu wajar jika muncul interpretasi 
subjektif sejarah demi kepentingan pendidikan (Mulyana, 2012:vi). Menurut S. Hamid Hasan ed. (2012), interpretasi subjektif itu lahir akibat materi dan interpretasi terhadap fakta sejarah tersebut bersumber dari kurikulum; sedangkan di pihak yang lain, kurikulum merupakan produk kebijakan politik pemerintah dalam bidang pendidikan (Hasan ed., 2012:118).

Pembuatan dan penggunaan buku teks pelajaran bukan semata-mata untuk buku pegangan yang akan mempermudah pelaksanaan pembelajaran, melainkan juga disusun dengan memperhatikan perkembangan usia atau jenjang pendidikan peserta didik (Sjamsuddin, 2007:195). Selain mempermudah pelaksanaan pembelajaran, penyusunan buku teks pelajaran sejarah pun harus memperhatikan perkembangan usia atau jenjang pendidikan peserta didik yang dituju.

Dengan demikian, tantangan dalam penulisan buku teks pelajaran sejarah berkisar pada dua hal, yang satu sama lain mungkin dipertentangkan. Pertama, sebagai karya historiografi, buku teks pelajaran sejarah mesti objektif yaitu berpijak dan menjunjung tinggi kaidah-kaidah kebenaran ilmu pengetahuan. Bagi Christopher Lloyd (1993), ilmu sejarah berdasarkan kaidah ilmu pengetahuan memiliki struktur umum yang berpijak dari landasan epistemologi, ontologi, dan semantik. Namun, menurut Arthur Marwick (2001), makna dalam narasi interpretatif berupa bahasa, yaitu kalimat dalam historiografi karya sejarawan juga dipengaruhi sikap, asumsi mentalitas, dan nilai-nilai yang dimilikinya ( $c f$ Mulyana, 2013:79).

Selain dituntut memenuhi kaidah kebenaran ilmu pengetahuan, buku teks pelajaran sejarah juga dituntut fungsinya sebagai alat pendidikan yang bersifat ideologis. Dalam hal inilah, ditengarai munculnya subjektivitas karena interpretasi sejarah itu lahir secara sepihak dari pemerintah atau pemegang kebijakan pendidikan (Suwirta, 2000a). Jadi, kebijakan pendidikan tentu saja produk kebijakan politik. Jika rencana besar pemerintah mengenai pendidikan terkandung dalam kurikulum, maka kurikulum pendidikan itu sendiri memiliki landasan politiknya (Hasan, 1996:45).

Menurut Nugroho Notosusanto (1978), secara teknis, objektivitas sejarah tidak mungkin tercapai, karena itu janganlah mengharapkan sesuatu yang tidak mungkin terjadi, yaitu mengharapkan sejarah yang objektif kepada sejarawan. Sejarawan bukan hanya bukan dewa dan bukan pula malaikat, melainkan juga sejarawan memiliki emosi. Selama penulis, termasuk sejarawan, memiliki emosi, maka subjektivitas mungkin terjadi. Jadi, soalnya ialah seberapa jauh subjektivitas yang masih dianggap pantas dan bagaimana yang dianggap tidak pantas lagi (Notosusanto, 1978:13).

S.K. Kochhar (2008) menegaskan bahwa salah satu aspek penting dalam pembelajaran sejarah adalah penanaman nilai. Nilai tersebut bisa bersifat politis, suatu nilai yang membantu perpolitikan dalam negeri. Dalam konteks inilah pelajaran sejarah, termasuk diantaranya buku teks pelajaran sejarah, dapat dipahami sebagai medium untuk menanamkan nilai kepada peserta didik, baik nilai-nilai bersifat politis yang menguatkan keberadaan dan membantu penciptaan stabilitas negara maupun nilai-nilai nonpolitis, atau setidaknya tidak kentara bersifat politis (Mulyana, 2013:79).

Dengan ukuran nilai tertentu, tentu saja menarik untuk menelusuri aspek positif dan negatif dari hubungan negara dengan legitimasi historis, ideologi, ideologisasi, pelajaran sejarah, dan buku teks pelajaran sejarah. Akan tetapi, dalam kesempatan ini, hal itu harus diabaikan, karena artikel ini akan fokus untuk membuktikan bahwa hubungan antara negara, legitimasi historis, ideologi, ideologisasi, pelajaran sejarah, dan buku teks pelajaran sejarah adalah terkait berkelindan dan merupakan suatu kenyataan yang tidak terbantahkan. 
Melalui artikel ini, kami hendak mengidentifikasi proses ideologisasi dalam buku teks pelajaran sejarah, yaitu misi-misi yang bersifat ideologis, yang telah ditetapkan pemerintah dalam buku teks pelajaran sejarah. Wabilkhusus, kami akan menyingkap ideologisasi konsep "Reformasi" dari pemerintah dalam Buku Sekolah Elektronik (BSE) Sejarah untuk SMA/MA Kelas XII Program IPA, karya Sh. Musthofa, Suryandari \& Tutik Mulyati (2009). Hal itu dilakukan dengan mengkaji bagian-bagian dalam buku teks, yang di dalamnya mengandung ideologisasi konsep "Reformasi”.

\section{METODE PENELITIAN}

Metode penelitian yang digunakan dalam penelitian ini adalah metode analisis isi (content analysis). Metode ini bekerja dengan mengumpulkan dan menganalisis muatan makna dari sebuah teks, yaitu teks narasi sejarah yang tertuang dalam buku teks yang berjudul Buku Sekolah Elektronik (BSE) Sejarah untuk SMA/MA Kelas XII Program IPA, karya Sh. Musthofa, Suryandari \& Tutik Mulyati (2009).

Metode analisis isi adalah salah satu bentuk metode kualitatif. Menurut Robert C. Bogdan \& S. Knop Biklen (1982) dan Lexi J. Moleong (2006), pendekatan kualitatif merupakan prosedur penelitian yang menghasilkan data deskriptif, yaitu data yang dikumpulkan berupa kata-kata, gambar, dan bukan angka-angka. Analisis isi adalah suatu model yang dipakai untuk meneliti dokumentasi data berupa teks, gambar, simbol, dan sebagainya (Bogdan \& Biklen, 1982; dan Moleong, 2006). ${ }^{1}$

Pada awalnya, analisis isi berkembang dalam bidang suratkabar yang bersifat kuantitatif. Richard W. Budd \& Robert K. Thorp (1963) mengemukakan bahwa analisis isi merupakan teknik sistematik

${ }^{1}$ Lihat juga, misalnya, http://digilib.uinsby.ac.id/9759/5/ bab\%203.pdf [diakses di Bandung, Indonesia: 22 Januari 2016]. untuk menganalisis isi pesan dan mengolah pesan, atau suatu alat untuk mengobservasi dan menganalisis perilaku komunikasi yang terbuka dari komunikator yang dipilih (Budd \& Thorp, 1963).

Penelitian dengan metode analisis isi digunakan untuk memperoleh keterangan dari komunikasi, yang disampaikan dalam bentuk lambang yang terdokumentasi atau dapat didokumentasikan. Metode ini dapat dipakai untuk menganalisa semua bentuk komunikasi, seperti bentuk komunikasi pada suratkabar, buku, film, dan sebagainya, sehingga akan diperoleh suatu pemahaman terhadap berbagai isi pesan komunikasi yang disampaikan, baik oleh media massa maupun dari sumber lainnya secara objektif, sistematis, dan relevan (cf Suwirta, 2000b dan 2015).

Menurut Klaus Kripendoff (1991), analisis isi bukan sekadar menjadikan isi pesan sebagai objeknya, melainkan juga terkait dengan konsepsi-konsepsi yang lebih baru tentang gejala-gejala simbolik dalam dunia komunikasi (Kripendoff, 1991). Analisis isi adalah teknik penelitian untuk membuat inferensi-inferensi atau keteranganketerangan yang dapat ditiru (replicable) dan sahih datanya dengan memperhatikan konteksnya (Suprayogo, 2001:71).

Sebagai suatu teknik penelitian, analisis isi mencakup prosedur-prosedur khusus untuk pemrosesan data ilmiah dengan tujuan memberikan pengetahuan, membuka wawasan baru, dan menyajikan fakta. Dengan menggunakan analisis isi terhadap dokumen buku teks yang berjudul Buku Sekolah Elektronik (BSE) Sejarah untuk SMA/MA Kelas XII Program IPA, karya Sh. Musthofa, Suryandari \& Tutik Mulyati (2009), maka secara kualitatif akan dapat diketahui apa saja pesan atau ideologisasi dalam buku teks tersebut.

Buku teks ini dipilih dan dijadikan sumber data karena ianya merupakan buku resmi atau official history, yang diterbitkan oleh pemerintah (cf Suwirta, 2010; dan Hasan ed., 
2012). Buktinya, ia diterbitkan oleh Pusat Perbukuan, Departemen Pendidikan Nasional di Jakarta. Dengan demikian, kemungkinan besar, interpretasi sejarahnya merupakan representasi dari misi, atau setidak-tidaknya isinya direstui oleh pemerintah (Sjamsuddin, 2000; dan Wiriaatmadja, 2003). Ketika menganalisis isi buku ini, maka akan tampaklah ideologisasi konsep "Reformasi" dari pihak pemerintah.

Metode analisis isi akan dioperasionalkan dengan teknik pemberian makna terhadap narasi sejarah Reformasi dalam buku teks tersebut, sehingga akan terkuaklah ideologisasi konsep "Reformasi”, yaitu proses pemberian pemaknaan terhadap peristiwa sejarah Reformasi tahun 1998, agar diyakini peserta didik.

\section{KAJIAN ISI: KONSEP REFORMASI}

Pada halaman 38, buku teks itu menjelaskan bahwa "Reformasi" merupakan perubahan bertahap, namun bersifat radikal dan menyeluruh untuk perbaikan. Tuntutan Reformasi ialah perubahan mendasar atas paradigma baru atau kerangka berpikir baru, yang dijiwai pandangan keterbukaan dan transparansi. Reformasi menghendaki perubahan kehidupan bermasyarakat, berbangsa, dan bernegara ke arah yang lebih baik secara konstitusional dalam berbagai bidang kehidupan. Ketika terjadi krisis ekonomi, politik, hukum, dan kepercayaan, seluruh rakyat mendukung Reformasi dan menghendaki pergantian pemimpin yang diharapkan dapat membawa perubahan Indonesia di segala bidang ke arah yang lebih baik (Musthofa, Suryandari \& Mulyati, 2009).

Gerakan Reformasi di Indonesia terjadi pada tahun 1998. Sebelum momentum ini, pertikaian sosial dan kekerasan politik terus berlangsung dalam masyarakat di berbagai daerah sepanjang tahun 1996. Kerusuhan meletus di Situbondo, Jawa Timur, pada bulan Oktober 1996. Kerusuhan serupa terjadi di Tasikmalaya, Jawa Barat, pada bulan Desember 1996. Tentu saja hal ini memengaruhi kondisi politik, sosial, dan ekonomi Indonesia (Musthofa, Suryandari \& Mulyati, 2009:39).

Setelah tiga dasawarsa dikuasai secara hegemonik oleh rezim Orde Baru, yang bercita-cita menciptakan stabilitas negara dengan membatasi kebebasan rakyat dalam berbicara dan berorganisasi, namun bersifat tertutup dan koruptif, kolutif, dan nepotisme, hingga terpaan krisis ekonomi tahun 1997, diperparah dengan krisis sosial dan kritis politik, maka gerakan kaum intelektual dan mahasiswa yang menuntut Reformasi, kian mengkristal. Gerakan ini menuntut pergantian Presiden dan menginginkan adanya penataan ulang pemerintahan (Musthofa, Suryandari \& Mulyati, 2009).

Tujuan gerakan Reformasi, diantaranya adalah Reformasi politik untuk mencapai demokratisasi, Reformasi ekonomi untuk mencapai kesejahteraan masyarakat, Reformasi hukum untuk mencapai keadilan bagi seluruh rakyat Indonesia, dan Reformasi sosial untuk mewujudkan integrasi bangsa (Musthofa, Suryandari \& Mulyati, 2009:4041). Gerakan Reformasi tahun 1998 menghendaki adanya pembaruan, perbaikan, dan perombakan aspek politik, ekonomi, hukum, dan sosial dalam pemerintahan.

Menurut keterangan dalam buku teks ini, penyebab langsung gerakan Reformasi tahun 1998, diantaranya, sejak tanggal 13 Mei 1998, rakyat meminta agar Soeharto mundur dari posisinya sebagai Presiden RI (Republik Indonesia). Pada tanggal 14 Mei 1998, terjadi kerusuhan di Jakarta dan Surakarta di Jawa Tengah. Tanggal 15 Mei 1998, Presiden Soeharto pulang dari KTT (Konferensi Tingkat Tinggi) G-15 di Kairo, Mesir. Sejak tanggal 18 Mei 1998, para mahasiswa menduduki gedung DPR/ MPR (Dewan Perwakilan Rakyat/Majelis Permusyawaratan Rakyat), kemudian Ketua DPR/MPR meminta Presiden Soeharto untuk mengundurkan diri. Di pihak lain, nilai tukar Rupiah merosot sampai Rp. 15,000 per Dolar Amerika Serikat. Tingkat 
kepercayaan publik di dalam dan di luar negeri terhadap Presiden Soeharto tampak rendah. Akhirnya, pada tanggal 21 Mei 1998, Presiden Soeharto menyatakan berhenti dan diganti oleh Presiden B.J. (Bacharuddin Jusuf) Habibie (Musthofa, Suryandari \& Mulyati, 2009:41).

Gerakan Reformasi ini disuburkan, atau menemukan momentumnya, pada pasca PEMILU (Pemilihan Umum) tahun 1997, dimana Soeharto terpilih kembali menjadi Presiden RI dan komposisi anggota DPR/ MPR terkesan kolutif dan nepotis, sedangkan rakyat hidup susah akibat krisis moneter di Asia Tenggara tahun 1997, yang membuat kurs Rupiah pada 1 Agustus 1997 meningkat drastis, dari Rp. 2,575 menjadi Rp. 5,000 per Dolar Amerika Serikat. Pada akhir tahun 1997, pemerintah melikuidasi 16 bank nasional, operasi 7 bank nasional dibekukan, dan nilai Rupiah terus melemah hingga Rp. 10,000 per Dolar Amerika Serikat, dan naiknya harga BBM (Bahan Bakar Minyak) dan ongkos angkutan umum (Musthofa, Suryandari \& Mulyati, 2009:38-39).

Dengan demikian, dalam buku teks ini, konsep "Reformasi” dimaknai sebagai proses pembaruan, perbaikan, dan perombakan pemerintahan secara bertahap. Hal ini berbeda dengan konsep "Revolusi", yang perubahannya bersifat seketika. Dalam buku teks ini, ideologisasi konsep "Reformasi” tampak dengan menempatkan rezim pemerintahan Orde Baru sebagai rezim kolot, buruk, dan gagal dalam mengelola negara; sedangkan gerakan Reformasi ditampilkan sebagai ikhtiar baru untuk merombak tatanan Orde Baru yang kolot, buruk, dan salah kelola itu (Musthofa, Suryandari \& Mulyati, 2009).

Dalam buku teks yang berjudul Buku Sekolah Elektronik (BSE) Sejarah untuk SMA/MA Kelas XII Program IPA, karya Sh. Musthofa, Suryandari \& Tutik Mulyati (2009), ideologisasi konsep Reformasi juga termaktub jelas dalam "Bab II: Perkembangan Masyarakat Indonesia pada
Masa Reformasi”. Bab ini terdiri atas tiga sub-bab: (1) "Kondisi Ekonomi dan Politik Sebelum Reformasi”; (2) "Perkembangan Politik Setelah 21 Mei 1998”; dan (3) "Kondisi Sosial dan Ekonomi Masyarakat di Berbagai Daerah Sejak Reformasi”. Bab ini disajikan setelah pembahasan "Bab I: Permbangunan Masyarakat Indonesia pada Masa Orde Baru”; dan sebelum pokok bahasan pertama semester 2, yaitu "Bab III: Hubungan Perkembangan Ilmu Pengetahuan dan Teknologi dengan Perang Dunia II serta Perang Dingin” (Musthofa, Suryandari \& Mulyati, 2009).

Dengan demikian, narasi historiografi perkembangan masyarakat Indonesia pada masa Reformasi, dalam buku teks ini, disajikan secara kronologis setelah membahas perkembangan masyarakat Indonesia pada masa Orde Baru (1966-1998). Hal ini tentu saja lebih memudahkan peserta didik dalam memahami materi tentang Reformasi, sebab bukan saja perkembangan masyarakat Indonesia pada masa Orde Baru diajarkan terlebih dahulu, tetapi juga narasi gerakan Reformasi yang menolak kelanjutan dan mengakhiri Orde Baru akan menemukan latar belakang masalahnya. Reformasi muncul pada masa pasca Orde Baru, gerakan mengoreksi pemerintahan Orde Baru, dan ditampilkan secara diametral pada titik bertentangan dengan Orde Baru.

Ideologisasi perihal dan menuturkan citra baik Reformasi terlihat jelas di awal paparan Bab II buku ini (Musthofa, Suryandari \& Mulyati, 2009:38). Pada paragraf dan kalimat pertama tertulis, "Reformasi merupakan perubahan yang radikal dan menyeluruh untuk perbaikan". Selanjutnya, pada paragraf kedua kalimat pertama terdapat penjelasan, sebagai berikut:

Reformasi menghendaki adanya perubahan kehidupan bermasyarakat, berbangsa, dan bernegara ke arah yang lebih baik secara konstitusional dalam berbagai bidang kehidupan (Musthofa, Suryandari \& Mulyati, 2009:38). 
Penjelasan tadi diikuti dengan keterangan bahwa gerakan ini dipicu adanya krisis dan dukungan rakyat. Perhatikan petikan kalimat berikut ini:

Ketika terjadi krisis ekonomi, politik, hukum, dan krisis kepercayaan, maka seluruh rakyat mendukung adanya Reformasi dan menghendaki adanya pergantian pemimpin yang diharapkan dapat membawa perubahan Indonesia di segala bidang ke arah yang lebih baik (Musthofa, Suryandari \& Mulyati, 2009:38).

Perkembangan politik yang buruk, pasca pelaksanaan PEMILU (Pemilihan Umum) tahun 1997 pada zaman Orde Baru, menjadi pusat perhatian tim penulis buku teks ini. Terdapat enam bukti untuk membenarkan hal ini. Pertama, meletusnya Peristiwa 27 Juli 1996, yang acapkali disingkat dengan sebutan Peristiwa KUDATULI (Kerusuhan 27 Juli), dengan pengrusakan terhadap gedung DPP PDI (Dewan Pimpinan Pusat Partai Demokrasi Indonesia) di Jakarta. Kedua, kuatnya tekanan pemerintah Orde Baru terhadap kekuatan oposisi, yang dibuktikan dengan pelarangan dibentuknya partai-partai politik, selain PPP (Partai Persatuan Pembangunan), GOLKAR (Golongan Karya), dan PDI berdasarkan Paket Undang-Undang Politik tahun 1985 (Musthofa, Suryandari \& Mulyati, 2009).

Selanjutnya, bukti yang ketiga, terjadinya pertikaian sosial dan kekerasan politik sepanjang tahun 1996. Keempat, PEMILU 1997, yang kembali melahirkan GOLKAR sebagai pemenang mutlak dan komposisi anggota DPR/MPR (Dewan Perwakilan Rakyat/Majelis Permusyawaratan Rakyat) yang mengandung nepotisme tinggi, bahkan hampir semua putera-puteri Soeharto masuk menjadi anggotanya, telah memperbesar dukungan mutlak lagi kepada Soeharto untuk terpilih kembali menjadi Presiden RI (Republik Indonesia) pada Sidang MPR tahun 1998. Kelima, kondisi ekonomi negara yang lemah, karena diterpa krisis moneter, sehingga rakyat semakin sengsara dan tidak mempercayai rezim Orde Baru. Keenam, menurunnya tingkat kepercayaan dunia terhadap Presiden Soeharto (Musthofa, Suryandari \& Mulyati, 2009).

Alhasil, pada tanggal 4 Mei 1998, aksi anti rezim Orde Baru kian meluas, bahkan pada tanggal 12 Mei 1998, aksi mahasiswa UNSAKTI (Universitas Trisakti) di Jakarta berubah menjadi bentrokan fisik yang membawa korban 4 mahasiswa meninggal dunia, yakni Elang Mulia, Hari Hartanto, Hendriawan, dan Hafiadin Royan, yang turut menyolidkan gerakan mahasiswa dalam menolak Orde Baru (Musthofa, Suryandari \& Mulyati, 2009). Jadi, narasi dalam buku teks sejarah ini bukan saja tersurat dan tersirat melihat akhir Orde Baru sebagai pemerintahan yang buruk, tidak dapat mengendalikan keadaan, dan tak lagi dipercaya rakyat dan pihak luar negeri, tetapi juga memaparkan argumentasi historis bahwa bergulirnya gerakan Reformasi merupakan kewajaran dan kebaikan belaka sebagai bentuk tanggapan (respond) atas bermasalahnya pemerintahan Orde Baru.

Selanjutnya, narasi buku teks sejarah ini menyajikan penjelasan tentang hal-hal terkait Reformasi di Indonesia pasca Presiden Soeharto menyatakan berhenti pada 21 Mei 1998, dalam sub-bab "Perkembangan Politik Setelah 21 Mei 1998”. Di bagian ini, tim penulis menjelaskan sebab-sebab terjadinya Reformasi. Pada paragraf dan kalimat pertama sub-bab, tim penulis mengatakan: "Sejak 13 Mei 1998, rakyat meminta agar Presiden Soeharto mengundurkan diri” (Musthofa, Suryandari \& Mulyati, 2009:40). Di sini, tim penulis memakai kata "rakyat" yang "meminta agar Presiden Soeharto mengundurkan diri”. Padahal, tiada penelitian sebelumnya bahwa rakyat (seluruhnya) meminta hal itu. Artinya, tim penulis tampak hendak meyakinkan (ideologisasi) bahwa pengunduran diri Presiden Soeharto ialah atas "keinginan rakyat”. 
Ideologisasi konsep mulia Reformasi tampak dalam pemaparan yang berulangulang oleh tim penulis buku teks ini berkenaan dengan tujuan Reformasi. Mereka menulis bahwa tujuan Reformasi adalah terciptanya kehidupan dalam bidang politik, ekonomi, hukum, dan sosial yang lebih baik dari masa sebelumnya (Musthofa, Suryandari \& Mulyati, 2009:40). Tentu saja, dalam pandangan para penulis buku teks, kehidupan bidang politik, ekonomi, hukum, dan sosial zaman pemerintahan Orde Baru belumlah sempurna, karena itu Reformasi hendak menyempurnakannya. Beberapa tujuan perbaikan Reformasi juga ditampilkan, misalnya dikatakan bahwa Reformasi politik bertujuan mencapai demokratisasi, Reformasi ekonomi untuk meningkatkan kesejahteraan masyarakat, Reformasi hukum untuk mewujudkan keadilan bagi seluruh rakyat Indonesia, dan Reformasi sosial untuk mewujudkan integrasi bangsa Indonesia (Musthofa, Suryandari \& Mulyati, 2009).

Penyajian faktor-faktor pendorong terjadinya Reformasi, secara tersurat, yang dikemukakan tim penulis menyimpulkan bahwa aspek-aspek politik, ekonomi, sosial, dan hukum dalam realitas kehidupan Orde Baru adalah realitas yang buruk dan - karena itu - dikritik dan dikoreksi oleh Reformasi (Musthofa, Suryandari \& Mulyati, 2009). Jadi, secara tersirat, tim penulis buku ini pun menggiring pemikiran pembaca agar memandang negatif pemerintahan Orde Baru, seraya memandang positif (baik) dan mendukung gerakan Reformasi di Indonesia.

Dengan tujuan untuk meyakinkan pembaca dari kalangan siswa SMA/ MA (Sekolah Menengah Atas/Madrasah Aliyah) Program IPA (Ilmu Pengetahuan Alam) Kelas XII tentang benar dan baiknya gerakan Reformasi, tim penulis buku teks menampilkan benang merah pengalaman suksesi (pergantian) Presiden RI (Republik Indonesia), terutama dari Presiden Soekarno ke Presiden Soeharto pada tahun 1966-1968; dan dari Presiden Soeharto kepada Presien B.J. (Bacharuddin Jusuf) Habibie pada tahun 1998. Dari situ dijelaskan substansi agenda Reformasi politik, ekonomi, hukum, sosial, dan pendidikan, serta hambatan pelaksanaan Reformasi politik (Musthofa, Suryandari \& Mulyati, 2009).

Menurut tim penulisnya, beberapa penyebab suksesi kepemimpinan Presiden RI dari Soekarno ke Soeharto, dari tahun 19661968, diantaranya karena problem pokok berupa ideologi Komunisme atau PKI (Partai Komunis Indonesia); terjadinya pembantaian beberapa elite milier dalam Peristiwa Lubang Buaya, pada tanggal 30 September dan 1 Oktober 1965; adanya dualisme sikap rakyat antara yang pro (mendukung) dan kontra (anti) pembubaran PKI; dan digelarnya Sidang Istimewa MPRS (Majelis Permusyawaratan Rakyat Sementara) tahun 1967, yang didahului oleh turunnya SUPERSEMAR atau Surat Perintah Sebelas Maret tahun 1966 (Musthofa, Suryandari \& Mulyati, 2009:41).

Beberapa pemandangan yang terjadi dalam peralihan Presiden RI, dari Presiden Soeharto ke Presiden B.J. Habibie pada tahun 1998, diantaranya adalah masalah pokok berupa terjadinya krisis ekonomi yang meluas kedalam krisis politik; adanya gerakan Reformasi yang menghendaki perubahan radikal karena kasus-kasus KKN (Korupsi, Kolusi, dan Nepotisme) dalam tubuh pemerintahan; serta Presiden Soeharto ditolak oleh rakyat yang ditandai dengan didudukinya gedung DPR/MPR oleh mahasiswa, sehingga Soeharto menyerahkan jabatan Presiden kepada B.J. Habibie (Musthofa, Suryandari \& Mulyati, 2009:41).

Ideologisasi konsep "Reformasi” tampak dalam paparan selanjutnya dari buku teks ini. Tim penulisnya menjelaskan beberapa hal. Pertama, Reformasi di bidang ideologi negara dan konstitusi. Kedua, pemberdayaan DPR, MPR, dan DPRD (Dewan Perwakilan Rakyat Daerah) agar lembaga perwakilan rakyat benar- 
benar melaksanakan fungsi perwakilannya sebagai aspek kedaulatan rakyat. Ketiga, Reformasi lembaga kepresidenan dan kabinet. Keempat, pembaruan kehidupan politik, yaitu memberdayakan partai politik untuk menegakan kedaulatan rakyat. Kelima, penyelenggaraan PEMILU. Keenam, birokrasi sipil mengarah pada terciptanya institusi birokrasi yang netral dan profesional. Ketujuh, peran sosial politik pihak militer dan Dwi Fungsi ABRI (Angkatan Bersenjata Republik Indonesia) dikurangi secara bertahap hingga hilang. Kedelapan, sistem pemerintah daerah dengan sasaran memberdayakan otonomi daerah dengan asas desentralisasi (Musthofa, Suryandari \& Mulyati, 2009:41-42).

Tim penulis buku teks ini menampilkan beberapa hambatan pelaksanaan Reformasi politik. Pertama, hambatan kultural, yaitu pergantian kepemimpinan nasional dari Presiden Soeharto kepada Presiden B.J. Habibie tidak diiringi pergantian rezim, yang berarti sebagian besar anggota kabinet, gubernur, birokrasi sipil, dan komposisi anggota DPR/MPR masih peninggalan rezim Orde Baru. Kedua, hambatan legitimasi, maksudnya bahwa pemerintahan B.J. Habibie masih dipertanyakan legitimasinya, karena ia terpilih bukan hasil PEMILU, melainkan mengganti Presiden Soeharto yang sebelumnya dipilih oleh MPR RI. Ketiga, hambatan struktural, dimana hambatan ini berkaitan dengan krisis ekonomi yang berlarut-larut, yang berdampak terhadap bertambah banyaknya rakyat yang hidup dalam kemiskinan. Keempat, munculnya berbagai tuntutan otonomi daerah, yang jika tidak ditangani secara baik akan menimbulkan disintegrasi bangsa. Kelima, adanya kesan kurang kuat dalam menegakan hukum terhadap praktek penyimpangan politik-ekonomi rezim lama, seperti praktek KKN. Keenam, terkotak-kotaknya elite politik, maka dibutuhkan kesadaran untuk bersama-sama menciptakan kondisi politik yang mantap agar transformasi politik berjalan lancar (Musthofa, Suryandari \& Mulyati, 2009).

Di bagian sub-bab 2 yang berjudul "Jatuh Bangunnya Pemerintahan RI Setelah 21 Mei 1998”, tim penulis buku teks ini menjelaskan bahwa MPR RI (Majelis Permusyawaratan Rakyat Republik Indonesia), yang diketuai Amien Rais, menyelenggarakan Sidang Umum pada tanggal 19 Oktober 1999, yang menolak Laporan Pertanggungjawaban Presiden B.J. Habibie, sebab diduga menguraikan indikator pertumbuhan ekonomi yang tidak akurat dan manipulatif, dan memilih Abdurrahman Wahid dan Megawati Soekarnoputri menjadi Presiden RI dan Wakil Presiden RI, periode 1999-2004. MPR RI membuat sembilan ketetapan dan untuk kali pertama melakukan amandemen terhadap UUD (Undang-Undang Dasar) tahun 1945 (Musthofa, Suryandari \& Mulyati, 2009).

Paparan di paragraf terakhir, halaman 43 hingga halaman 44, dapat disimpulkan bahwa alih-alih baik, kinerja pemerintahan Presiden Abdurrahman Wahid (1999-2001) malah lebih banyak buruknya. Dikatakan bahwa pemerintahan Presiden Abdurrahman Wahid berjasa dalam membuka kran kebebasan berpendapat dalam rangka demokrasi di Indonesia. Akan tetapi, kebebasan berpendapat itu malah membuat rakyat bingung dan bimbang mengenai benar atau tidaknya suatu hal. Pemerintah juga tidak pernah tegas dalam memberikan pernyataan terhadap suatu masalah. Di pihak lain, pemerintahan Presiden Abdurrahman Wahid belum dapat melepaskan bangsa Indonesia dari krisis ekonomi, dan malah memperluas disintegrasi bangsa serta transparannya pertentangan antara lembaga kepresidenan dengan DPR RI atau Dewan Perwakilan Rakyat Republik Indonesia (Musthofa, Suryandari \& Mulyati, 2009).

Hal yang terakhir, disebutkan disajikan dengan sejumlah alasan: teguran DPR tidak pernah diindahkan Presiden, kasus Bruneigate dan terutama Bulog-gate menyebabkan 
DPR mengeluarkan teguran keras berupa Memorandum I dan II kepada Presiden, namun tidak diindahkan Presiden, sehingga DPR meminta MPR untuk menyelenggarakan Sidang Istimewa. Dikatakan bahwa Presiden berusaha menyelesaikan masalah laporan pertanggungjawaban dengan kompromi politik, tetapi mayoritas anggota DPR menolaknya. Akhirnya, MPR bersikap tegas untuk menggelar Sidang Istimewa pada tanggal 21 Juli 2001, pasca Presiden Abdurrahman Wahid secara sepihak melantik pemangku sementara jabatan KAPOLRI (Kepala Kepolisian Republik Indonesia), Komisaris Jenderal (Pol) Chaerudin Ismail, mengganti KAPOLRI Jenderal Suroyo Bimantoro yang dinon-aktifkan (Musthofa, Suryandari \& Mulyati, 2009).

Sikap Presiden Abdurrahman Wahid bukan saja menolak penyelenggaraan dan menyatakan Sidang Istimewa MPR sebagai tidak sah dan ilegal, namun juga mengeluarkan Dekrit Presiden RI pada 23 Juli 2001, yang berisi perintah pembekuan MPR dan DPR RI, mengembalikan kedaulatan ke tangan rakyat, dan mengambil tindakan serta menyusun badan-badan untuk menyelenggarakan PEMILU (Pemilihan Umum) dalam waktu satu tahun, serta menyelamatkan gerakan Reformasi total dari hambatan unsur-unsur Orde Baru, dengan membekukan Partai GOLKAR (Golongan Karya) sambil menunggu keputusan dari MA atau Mahkamah Agung (Musthofa, Suryandari \& Mulyati, 2009).

Disebutkan oleh tim penulis buku teks ini bahwa dalam menanggapi dektrit tersebut, bangsa Indonesia bimbang. Akhirnya, pada 23 Juli 2001, MPR menyatakan Dekrit Presiden Abdurrahman Wahid tidak sah dan Presiden dinilai telah melanggar haluan negara. Sikap MPR ini didukung fatwa MA. Akhirnya, MPR pun memberhentikan Presiden Abdurrahman Wahid dan menetapkan Megawati Soekarnoputri sebagai Presiden RI dan Hamzah Haz sebagai Wakil Presiden RI sampai tahun 2004 (Musthofa,
Suryandari \& Mulyati, 2009).

Di bagian itu, bukan saja tim penulis menyajikan narasi pemerintahan RI pada masa-masa awal Reformasi atau setelah 21 Mei 1998 yang jatuh-bangun, tetapi juga ditampilkan bahwa di samping memiliki sisi baik, dalam pemerintahan Presiden Abdurrahman Wahid, juga terdapat sisi buruknya (tidak Reformis). Narasi fakta dan alasan yang dikemukakan memperlihatkan bahwa langkah MPR yang memberhentikan Presiden Abdurrahman Wahid seraya memilih Megawati dan Hamzah Haz menjadi Presiden dan Wakil Presiden RI adalah tepat (Reformis) dan lebih banyak mendapat dukungan rakyat (Musthofa, Suryandari \& Mulyati, 2009).

Pada halaman 47 sampai halaman 48 dalam buku teks ini, tim penulis mengulas sub-bab 3 "Kondisi Sosial dan Politik Bangsa Indonesia Setelah 21 Mei 1998”. Di bagian ini diulas penyelenggaraan Referendum yang berakhir dengan berpisahnya Provinsi Timor Timur dari NKRI (Negara Kesatuan Republik Indonesia). Lain dari itu, dijelaskan pula tentang masih adanya gerakan untuk memisahkan diri dari NKRI di Aceh dan Irian Jaya. Dua daerah ini akhirnya diberi nama baru, yaitu Nanggroe Aceh Darussalam dan Papua; serta diberikan pula status baru yaitu daerah otonomi khusus, namun masih terjadi konflik bersenjata di Papua, bahkan di Aceh sehingga pemerintah Megawati Soekarnoputri, dengan persetujuan DPR, melaksanakan operasi militer di DOM (Daerah Operasi Militer) agar Papua dan Aceh masih merupakan bagian dari NKRI (Musthofa, Suryandari \& Mulyati, 2009).

Dikatakan pula bahwa gejolak politik di era Reformasi ditandai dengan banyaknya teror bom. Setelah teror bom terbesar meledak di tempat hiburan di Legian, Kuta, Bali, teror bom selanjutnya di Hotel J.W. Marriot, Jakarta, pada 12 Oktober 2002. Kondisi tak aman dan banyaknya 
teror bom memperburuk citra Indonesia di dunia internasional, sehingga banyak investor membatalkan niatnya untuk menanamkan modal di Indonesia. Hal ini diperparah dengan tidak tegaknya hukum dan HAM (Hak Asasi Manusia), terutama menyangkut para tokoh politik, konglomerat, dan oknum TNI (Tentara Nasional Indonesia). Alhasil, rakyat semakin tak percaya pada penguasa, meski telah dua kali terjadi pergantian Presiden sejak Soeharto mundur pada tahun 1998 (Musthofa, Suryandari \& Mulyati, 2009).

Di halaman 49 sampai halaman 51, dalam sub-bab C, "Kondisi Sosial dan Ekonomi Masyarakat di Berbagai Daerah Sejak Reformasi”, tim penulis buku teks ini memaparkan tentang besarnya tuntutan rakyat terhadap terjadinya perbaikan di berbagai aspek di zaman Reformasi. Namun, tuntutan itu malah disalahgunakan oleh para petualang politik, yang hanya untuk memuaskan kepentingan pribadi dan kelompoknya. Kekacauan hukum dan ekonomi akhirnya mempermudah sulutan konflik bersifat etnis dan antar agama di masyarakat di berbagai daerah. Konflik sosial yang melibatkan beberapa etnik terjadi di Kalimantan Barat, Kalimantan Tengah, Sulawesi Tengah, dan Maluku (Musthofa, Suryandari \& Mulyati, 2009).

Dari beberapa kejadian konflik dalam masyarakat di berbagai daerah itu, tim penulis buku teks ini menyatakan bahwa telah terjadi pergeseran pelaku kekerasan di Indonesia pada masa-masa awal Reformasi. Di zaman Orde Baru, kekerasan lebih banyak dilakukan oleh oknum militer atau ABRI (Angkatan Bersenjata Republik Indonesia), tetapi pada masa-masa awal Reformasi, kekerasan malah lebih banyak dilakukan oleh sesama warga sipil. Masyarakat bukan saja semakin beringas, melainkan juga hukum seperti tidak ada dan masyarakat semakin tidak percaya terhadap kinerja para penegak hukum. Sebabnya, ungkap tim penulis buku teks ini, karena masyarakat sudah muak melihat berbagai kasus besar yang melibatkan pejabat negara dan oknum militer tidak tertangani tuntas, meski telah dinyatakan bersalah (Musthofa, Suryandari \& Mulyati, 2009).

Keadaan ekonomi Indonesia selama tiga bulan masa kekuasaan Presiden B.J. Habibie (1998-1999) masih mengalami krisis. Rakyat banyak yang kesusahan, sehingga penjarahan menjadi tampak biasa. Pemerintah tampak tak berwibawa, sedangkan para penegak hukum tidak berkutik. Pemerintah menerima saran dari Bank Dunia (World Bank) dan Dana Moneter Internasional (International Monetary Fund) untuk memulihkan kondisi perekonomian nasional, namun hal itu malah kian memperburuk keadaan. Atas saran dari dua lembaga itu, pemerintah mencabut subsidi untuk listrik, BBM (Bahan Bakar Minyak), dan telepon. Akibatnya, bukan saja terjadi kenaikan biaya kebutuhan rakyat, namun juga hidup rakyat kian terjepit. Atas desakan rakyat, pemerintah Presiden Megawati Soekarnoputri (20012004) kemudian menghentikan kerja sama dengan dua lembaga tadi; namun pada pihak yang lain, para bankir malah memperburuk keadaan dengan membawa lari dana penyehatan bank, yakni dana BLBI (Bantuan Likuiditas Bank Indonesia), yang mereka peroleh dari bantuan pemerintah (Musthofa, Suryandari \& Mulyati, 2009).

Bagian akhir dari paparan buku teks ini memperlihatkan pandangan yang optimistik terhadap pemerintahan pasca Reformasi. Dikatakan bahwa pemerintah pasca Reformasi tetap berusaha memulihkan keadaan ekonomi dan segala cara dilakukan agar rakyat Indonesia segera terlepas dari krisis. Dituliskan pula bahwa partisipasi setiap warga negara sangat diharapkan untuk memulihkan keadaan dalam rangka mewujudkan masyarakat yang adil dan makmur, sesuai dengan Pembukaan UUD (Undang-Undang Dasar) tahun 1945 (Musthofa, Suryandari \& Mulyati, 2009). 
Dengan demikian, arti subjektif sejarah ini bagi negara ialah berlangsungnya negara dan masih bertahannya pemerintahan Reformasi.

\section{KESIMPULAN $^{2}$}

Buku teks pelajaran sejarah merupakan salah satu bentuk historiografi (tulisan sejarah) yang disusun untuk kepentingan pendidikan. Dalam historiografi jenis ini, berbagai peristiwa sejarah dipilih dan ditafsirkan untuk kepentingan mendidik siswa-siswi di sekolah. Narasi sejarah yang diisi fakta secara kronologis dan tafsiran sejarah yang bersifat mendidik itulah yang disebut sebagai "ideologisasi”, yaitu mentransmisikan ideologi atau pandangan pemerintah terhadap para peserta didik di sekolah, sehingga pandangan para peserta didik akan sama, sebagaimana yang dikehendaki oleh pemerintah yang berkuasa.

Sebagai salah satu konsep penting dalam sejarah Indonesia kontemporer, konsep "Reformasi” juga diideologisasikan ke tengah-tengah peserta didik melalui buku teks pelajaran sejarah. Dalam buku teks sejarah, bukan saja konsep Reformasi bermakna dan diopinikan baik, sedangkan zaman pemerintahan Orde Baru (19661998) bersifat buruk, melainkan juga para pembacanya diarahkan untuk menyetujui sikap tim penulis yang adalah juga sikap resmi pemerintah, bahwa pemerintahan Orde Baru yang buruk itu harus dikoreksi oleh pemerintahan Reformasi (1998-sekarang).

Betapa pun masih mengalami banyak kendala, namun dikatakan bahwa

\footnotetext{
${ }^{2}$ Artikel ini, sebelum dikemas-kini dan diedit-ulang oleh penulis kedua dalam bentuknya sekarang, merupakan tugas UAS (Ujian Akhir Semester) penulis pertama, pada matakuliah Historiografi Buku Teks Pelajaran Sejarah, yang diampu oleh Dr. Agus Mulyana pada Program Studi Pendidikan Sejarah di SPs UPI (Sekolah Pascasarjana, Universitas Pendidikan Indonesia) di Bandung, pada Semester 2, Tahun Pelajaran 2014-2015. Kami mengucapkan terima kasih kepada semua pihak yang telah membantu kelancaran proses penulisan artikel, walaupun seluruh isi dan interpretasi dalam artikel ini tetap menjadi tanggungjawab akademik kami berdua, selaku penulis.
}

Reformasi ialah langkah tepat dan memberi optimisme bagi bangsa ini dalam mencapai tujuan pembentukan negara Indonesia, sebagaimana yang termaktub dalam Pembukaan UUD (Undang-Undang Dasar) tahun $1945 .^{3}$

\section{Referensi}

Althusser, Louis. (t.t.). Tentang Ideologi: Marxisme, Strukturalis, Psikoanalisis, Cultural Studies. Yogyakarta: Penerbit Jalasutra, Terjemahan.

Bogdan, Robert C. \& S. Knop Biklen. (1982). Qualitative Research for Education: An Introduction to Theory and Methods. London and Boston: Sage Publications.

Budd, Richard W. \& Robert K. Thorp. (1963). An Introduction to Content Analysis: Including Annotated Bibliography. Iowa: University of Iowa School of Journalism.

Budiardjo, Mirriam. (1985). Dasar-dasar Ilmu Politik. Jakarta: PT Gramedia.

Hasan, S. Hamid. (1996). Pendidikan Ilmu Sosial. Jakarta: Departemen Pendidikan dan Kebudayaan.

Hasan, S. Hamid. (2000). "Kurikulum dan Buku Teks Sejarah” dalam HISTORIA: Jurnal Pendidikan Sejarah, Vol.1(1), Juni, hlm.13-28. Bandung: Jurusan Pendidikan Sejarah FPIPS UPI [Fakultas Pendidikan Ilmu Pengetahuan Sosial, Universitas Pendidikan Indonesia].

Hasan, S. Hamid [ed]. (2012). Pendidikan Sejarah Indonesia: Isu dalam Ide dan Pembelajaran. Bandung: Rizqi Press.

Hoare, Q. \& G.N. Smith [eds]. (1971). Selections from the Prison Notebooks of Antonio Gramsci. London: Lawrence and Wishart, Translation.

http://digilib.uinsby.ac.id/9759/5/bab\%203.pdf [diakses di Bandung, Indonesia: 22 Januari 2016].

Kochhar, S.K. (2008). Pembelajaran Sejarah. Jakarta: PT Grasindo, Terjamahan oleh Purwanta \& Yovita Hardiati.

Kripendoff, Klaus. (1991). Analisis Isi: Pengantar Teori dan Metodologi. Jakarta: Rajawali Press, Terjemahan.

Lloyd, Christopher. (1993). The Structures of History. London: Wiley-Blackwell.

\footnotetext{
${ }^{3}$ Pernyataan: Dengan ini, kami menyatakan bahwa artikel ini adalah karya asli kami berdua, ianya bukan hasil jiplakan, karena sumber-sumber rujukan yang kami kutip dinyatakan secara jelas dalam daftar Referensi. Artikel ini juga belum pernah direviu dan belum pernah diterbitkan oleh jurnal ilmiah lain.
} 
Marwick, Arthur. (2001). The New Nature of History: Knowledge, Evidence, Language. New York: Palgrave Macmillan.

Moleong, Lexi J. (2006). Metode Penelitian Kualitatif. Bandung: Remaja Rosda Karya.

Mulyana, Agus. (2012). "Pendidikan Sejarah, Nilai, dan Subjektivitas Interpretasi” dalam S. Hamid Hasan [ed]. Pendidikan Sejarah Indonesia: Isu dalam Ide dan Pembelajaran. Bandung: Rizqi Press.

Mulyana, Agus. (2013). "Nasionalisme dan Militerisme: Ideologisasi Historiografi Buku Teks Pelajaran Sejarah SMA” dalam Jurnal Paramita, Vol.23, No.1 [Januari].

Musthofa, Sh., Suryandari \& Tutik Mulyati. (2009). Buku Sekolah Elektronik (BSE) Sejarah 3 untuk SMA/MA Kelas XII Program IPA. Jakarta: Pusat Perbukuan, Departemen Pendidikan Nasional.

Noer, Deliar. (1982). Ideologi, Politik, dan Pembangunan. Jakarta: Yayasan Perkhidmatan.

Notosusanto, Nugroho. (1978). Masalah Penelitian Sejarah Kontemporer (Suatu Pengalaman). Jakarta: Yayasan Idayu.

Sjamsuddin, Helius. (2000). "Penulisan Buku Teks Sejarah: Kriteria dan Permasalahannya” dalam HISTORIA: Jurnal Pendidikan Sejarah, Vol.1(1), Juni, hlm.1-12. Bandung: Jurusan Pendidikan Sejarah FPIPS UPI [Fakultas Pendidikan Ilmu Pengetahuan Sosial, Universitas Pendidikan Indonesia].

Sjamsuddin, Helius. (2007). Metodologi Sejarah. Yogyakarta: Penerbit Ombak.

Suprayogo, Imam. (2001). Metode Penelitian Sosial Agama. Bandung: Remaja Rosda Karya.

Suwirta, Andi. (2000a). “Mengkritisi Peristiwa G30S
1965: Dominasi Wacana Sejarah Orde Baru dalam Sorotan” dalam HISTORIA: Jurnal Pendidikan Sejarah, Vol.1(1), Juni, hlm.43-49. Bandung: Jurusan Pendidikan Sejarah FPIPS UPI [Fakultas Pendidikan Ilmu Pengetahuan Sosial, Universitas Pendidikan Indonesia].

Suwirta, Andi. (2000b). Suara dari Dua Kota: Revolusi Indonesia dalam Pandangan Suratkabar Merdeka (Jakarta) dan Kedaulatan Rakyat (Yogyakarta), 1945-1947. Jakarta: PN Balai Pustaka.

Suwirta, Andi. (2010). "Dua Negara-Bangsa Melihat Masa Lalunya: Konfrontasi Indonesia-Malaysia (1963-1966) sebagaimana Dikisahkan dalam Buku-buku Teks Sejarahnya di Sekolah” dalam SOSIOHUMANIKA: Jurnal Pendidikan Sains Sosial dan Kemanusiaan, Vol.3(2), November, hlm.243-258.

Suwirta, Andi. (2015). Revolusi Indonesia dalam News \& Views: Sebuah Antologi Sejarah. Yogyakarta: Penerbit Ombak.

Wiriaatmadja, Rochiati. (2000). "Sejarah dan Pendidikan Sejarah Menghadapi Tantangan Abad ke-21" dalam HISTORIA: Jurnal Pendidikan Sejarah, Vol.1(1), Juni, hlm.29-36. Bandung: Jurusan Pendidikan Sejarah FPIPS UPI [Fakultas Pendidikan Ilmu Pengetahuan Sosial, Universitas Pendidikan Indonesia].

Wiriaatmadja, Rochiati. (2003). Pendidikan Sejarah di Indonesia: Perspektif Lokal, Nasional, dan Global. Bandung: Historia Utama Press.

Wood, Michael. (2013). Sejarah Resmi Indonesia Modern: Versi Orde Baru dan Para Penentangnya. Yogyakarta: Penerbit Ombak, Terjemahan. 